Polgári Szemle, 16. évf. 1-3. szám, 2020, 10-12., DOI: 10.24307/psz.2020.0702

\title{
Have We Got a Historical Success behind Us or the Ability of Permanent Renewal in Front of Us?
}

\section{Welcome by the Editor-in-Chief}

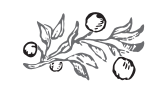

Journal of Economic Literature (JEL) codes: B20, N01

Keywords: economic policy, new system of public finances, Covid-19, Hungary

In one of his ballads, François Villon, the globally best known, most popular and most subjective French poet of the heyday of Renaissance neatly referred to life running out of time writing that "Like seconds, minutes the years fly by".

This is perceived by people who live a meaningful life and who enjoy life, and in the case of promising and happy periods. But if God is gracious to us, the momentum for a successful continuation will not fade for a long time.

Although the history of the Hungarian economy does not abound in successful periods, what we have and have accomplished deserves attention. The period of the Austro-Hungarian Monarchy, when independence was brought to completion and the economy was reinforced to build capitalism in Hungary with effective government support, and then, taking a huge leap, as we practically lost the 20th century, the past ten years of economic reorganisation, or the Hungarian model, both merit special attention.

The territorial, economic and population losses suffered after World War I, the hell of Second World War, and then the Soviet occupation and the concomitant political and economic regimes were not necessarily the most successful periods in Hungary's history. Similarly, the Neoliberal market economy that followed the collapse of planned economy without any kind of transition was more destructive than constructive. What is more, let us be precise: it did actually do more harm than good. The Hungarian economy had to wait for a hundred years to find its feet again and start to develop on its own, allowing society to prosper. Both in finances and in spirit.

Although at the turn of the millennium, there was a short "heart-warming" period, to quote György Matolcsy, who referred to the successful period of the Széchenyi 
National Development Plan, fate was not kind to us after 2002. The fiscal alcoholism of the liberal governments that came to power, the central bank's policy apathetic to the society and to Hungarian economy, and then to cap it all, the shadows of the 2007-2008 global crisis caused economic recession, unemployment, indebtedness and vulnerability to the rest of the world in terms of the economy and politics.

However, as from 2010 changes started in the political and then in the economic space. Hungary was reinforced by the macro-economic and social impacts of the statutory regulations codified on the basis of the chapter on public finances in the Fundamental Law and on middle-class values, completion of the competences and methodology of budgetary and fiscal control, the enforcement of public burden sharing, the expansion of the system of support to families, and then after 2013, the change in the monetary regime. Debt and the inflation dropped, earnings and incomes increased, and consequently, both the country's and the society's confidence improved. The scholarly concepts that academically map the economic and social logic behind the Hungarian model are springing. After decades in the spirit of Bokros and Gyurcsány, austerity programmes were replaced by developments and financial growth became the standard. The liberal economic policy based on ransoming families, local governments and Hungarian businesses has failed and lost confidence, and the academic circles advocating the "professionalism" of tax hikes and subsidy cuts are no longer in the lead. Naturally, not everything is in order in academic life, despite the fact that changes have begun at the Hungarian Academy of Sciences, because the middle range of the academic sector, and primarily university education in social sciences, has not altered one iota in 10 years. If four centuries after the spread of European book printing the poet Vörösmarty could still ask the question: "Is the world no better for any book?", then we certainly have a good reason to disbelieve and carry on changes. Until a country's intellectual élite is unable to produce and generate an authentic source, an intellectual register and a scientific background to its social and economic formation, problems keep arising, and the conditions are not in place for the next move, in the social, economic and public law sense of the term, even when there is sufficient political will.

As in The Ballad of La Danse Macabre, Villon wrote "With ringing bells - at Reims arrived the plague". At the beginning of 2020, right at the peak of our growth trajectory, a pandemic and its economic impacts derailed our progress by keeping labour off the workplace, thus reducing production and income, although in such a situation products and services are not in such a high demand as during a boom. Will and can our momentum wane as a result? Can our worldview socialised on growth and successes collapse? - the questions may arise in the reader.

In order to avoid any problems that may arise from overheating our economy and the exhaustion of our growth cycle, at the peak of our trajectory we were increasingly interested in the maintenance of our competitiveness and ability to develop. Now, having perceived the impacts of the pandemic, even more focus is given to the new challenges of the 21st century, the regional approach, in other words, the manner of counteracting the world-conquering nature of globalisation, digitisation, the revolu- 
tion of money, the change of its traditional role and appearance, the spread of a more environment-friendly green economy, the transforming consumer and social habits, life-style, and perhaps arising from all these, the aging of societies, and the endemic giving up of having children. These are challenges and although the years when we had to pay less attention to them have passed, we are hard pressed for time to comply with the relevant requirements. We were slow to respond and now we are in a compulsion to move, as in addition to avoid the trap of growth, the Hungarian economy and social policy must respond to the new challenges of the new world order and make sure that we stand up to both the society and external competitors, and remain competitive and successful.

The crisis hit us "loaded", in full swing. Unemployment is on the rise and the budget deficit is temporarily increasing for reasons beyond the government's or the central bank's policy, due to unpredictable extraneous circumstances. This situation differs from the one seen in 2008, when heedlessly overspending liberal governments pushed us into a debt trap on a state, corporate and family level alike. The coordinated actions taken by the government and the central bank, and primarily on the basis of the significant economic potential built so far, we now have the strength to defend ourselves and will have sufficient resources for consolidation. However, this will go further than just setting back to track and regaining the economic trajectory that characterised the country at the beginning of 2020. The role of knowledge and efficient business management will be given even more value and will change economic policy and corporate operation, including workers' approach and attitude to work. Life will accelerate. More than ever. Keeping pace is hardly possible, unless the standard and content of higher education are altered.

The Hungarian issues 1-3, Volume 16 of our journal focus on this new world order and its key criteria. The authors, ranging from the Governor of the National Bank of Hungary to young researchers, explore the economic and social impacts of the Covid-19 pandemic. We continue to complete our scientific mission of familiarising our readers with the scholarly analysis of the changing world.

It is worth reading Polgári Szemle.

Dr. Csaba Lentner, university professor

Editor-in-chief of Polgári Szemle 